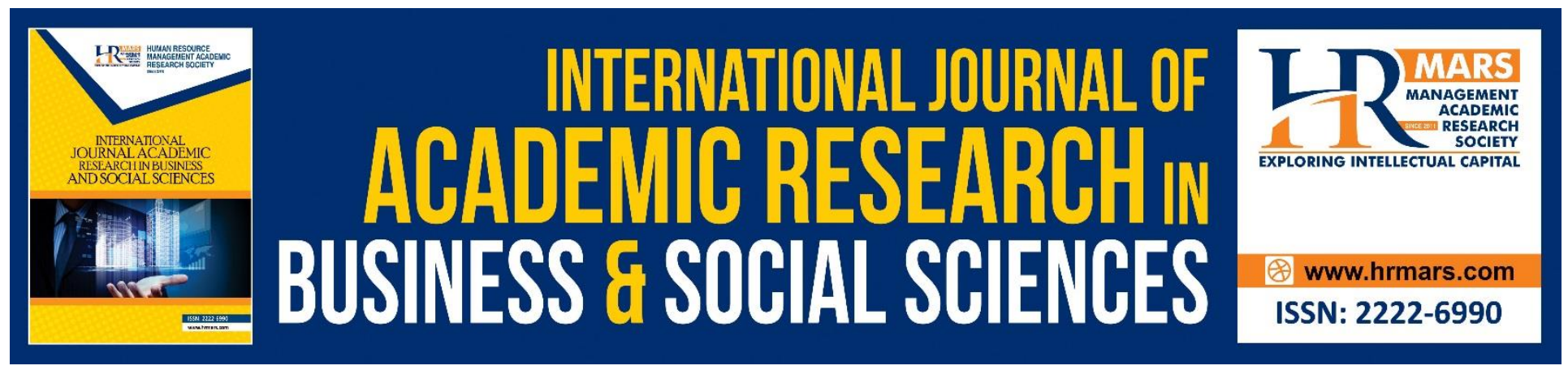

\title{
Does Monetary Policy and Asean Stock Market Affect Jakarta Composite Index (IHSG)?
}

Abd. Jamal, Julfahmi Salim, Chenny Seftarita, Mohd. Sadad Mahmud, Wan Mohd Nazri Wan Daud, Puspa Liza Ghazali, Norfadzilah Rashid

To Link this Article: http://dx.doi.org/10.6007/IJARBSS/v8-i12/5120

DOI: $10.6007 /$ IJARBSS/v8-i12/5120

Received: 05 Nov 2018, Revised: 11 Dec 2018, Accepted: 26 Dec 2018

Published Online: 29 Dec 2018

In-Text Citation: (Jamal et al., 2018)

To Cite this Article: Jamal, A., Salim, J., Seftarita, C., Mahmud, M. S., Daud, W. M. N. W., Ghazali, P. L., \& Rashid, N. (2018). Does Monetary Policy and Asean Stock Market Affect Jakarta Composite Index (IHSG)? International Journal of Academic Research in Business and Social Sciences, 8(12), 1236-1248.

Copyright: (C) 2018 The Author(s)

Published by Human Resource Management Academic Research Society (www.hrmars.com)

This article is published under the Creative Commons Attribution (CC BY 4.0) license. Anyone may reproduce, distribute, translate and create derivative works of this article (for both commercial and non-commercial purposes), subject to full attribution to the original publication and authors. The full terms of this license may be seen

at: http://creativecommons.org/licences/by/4.0/legalcode

Vol. 8, No. 12, 2018, Pg. 1236 - 1248

Full Terms \& Conditions of access and use can be found at http://hrmars.com/index.php/pages/detail/publication-ethics 


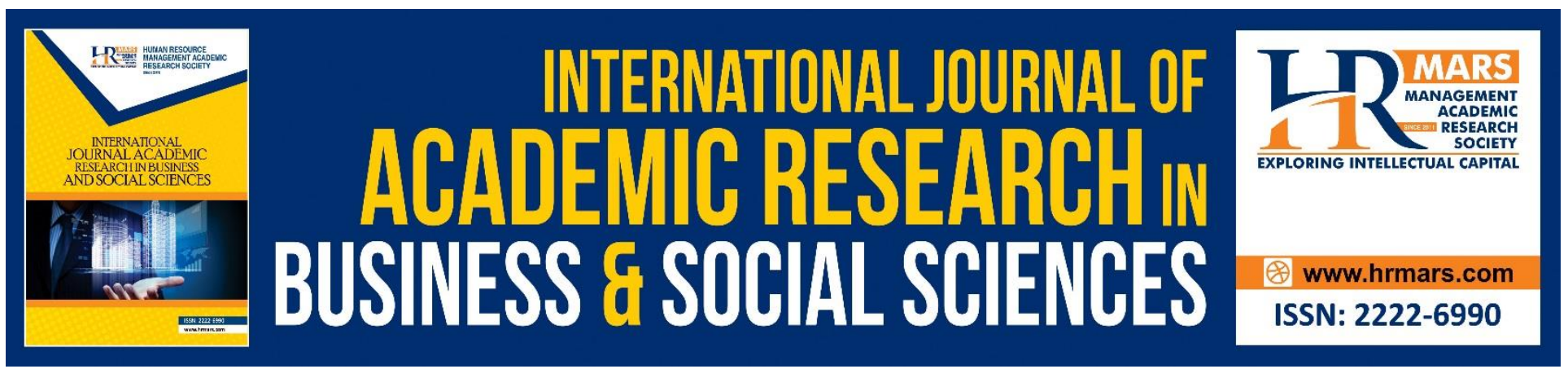

\title{
Does Monetary Policy and Asean Stock Market Affect Jakarta Composite Index (IHSG)?
}

\author{
Abd. Jamal ${ }^{1}$, Julfahmi Salim², Chenny Seftarita ${ }^{3}$ Mohd. Sadad \\ Mahmud $^{4}$, Wan Mohd Nazri Wan Daud ${ }^{5}$, Puspa Liza Ghazali6, \\ Norfadzilah Rashid ${ }^{7}$ \\ 1,2,3Faculty of Economics and Business of Syiah Kuala Universit \\ ${ }^{4,5,6}$ Faculty of Economics and Management Sciences, University Sultan Zainal Abidin \\ Email:mohdsadad@unisza.edu.my
}

\begin{abstract}
This study aims to analyze the effect of monetary policy and Kuala Lumpur Stock Exchange (KLSE) on the Jakarta Composite Index (IHSG) in Indonesia. The monthly secondary data from June 2005 to June 2016 is used in this analysis by using Vector Autoregressive (VAR) Model. The result shows that both exchange rate and KLSE have positive sign and significant, while BI-RATE has negative sign and significant. Based on the results, the authors suggested that the government in this case Indonesian Central Bank has to be careful in deciding the benchmark interest rate (BI-Rate) to maintain the stability of exchange rate, so that IHSG was able to show a positive trend.
\end{abstract}

Keywords: IHSG, Exchange rate, and BIRATE, KLSE,VAR indifference

\section{Introduction}

In the global economy where the economic integration becomes a choice in generating national economic activities, the national economic development cannot be separated from the economic development in the rest of the nation. In the era, the movement of goods and services and also capital can ease and freely move from a country to others by ignoring the limitation of distances. Time and space are not constraint in economic development escalation. The investment in capital markets is one of the economic activities that are able to do activities in a country or outside the country, where someone does not physically need to do the activities in purpose capital market. But he rather uses and takes advantages of the technology information in his business and economic activities. The global financial crisis in 2008, which was triggered by the bankruptcy of Lehman Brothers in USA had led many financial institutions collapsed in many countries (Lindström \& Giordano, 2016). The IMF report said that based on the experience in the past two decades, global financial occurs on average 2.5 years (IMF, 2012). Furthermore, it was said that the impact of the global financial crisis through two types of shock, namely trade shock and financial shock. The impact of the crisis changed 
INTERNATIONAL JOURNAL OF ACADEMIC RESEARCH IN BUSINESS AND SOCIAL SCIENCES Vol. 8, No. 12, Dec, 2018, E-ISSN: 2222-6990 @ 2018 HRMARS

investor's behavior from risky to safer investment, such as in Malaysian case (Mustafa, Samsudin, Shahadan, \& Yi, 2015). So far, the financial crisis which began from the developed countries has caused the lower economic growth in many developing countries and also boosted unemployment and poverty (Fîrţescu, 2012), even though some emerging market economies could easily recovered from the crisis, particularly, in Asia and Latin America (Dao, 2017). In addition, as a result of the global financial crisis, several MENA countries (Middle East and North Africa) experienced a significant economic downturn. The stock market MENA plummeted, the price of real estate assets fell, private debt increased and the economy grow at negative level. On the other hand, in the south and east Asia, the economy is in transition economies and the countries of Latin America and the Caribbean cannot be separated from the influence of the global crisis that resulted also the MENA countries as well as various countries in Asia, primarily due to large economic integration (Neaime, 2012; Chen, et al; 2014).

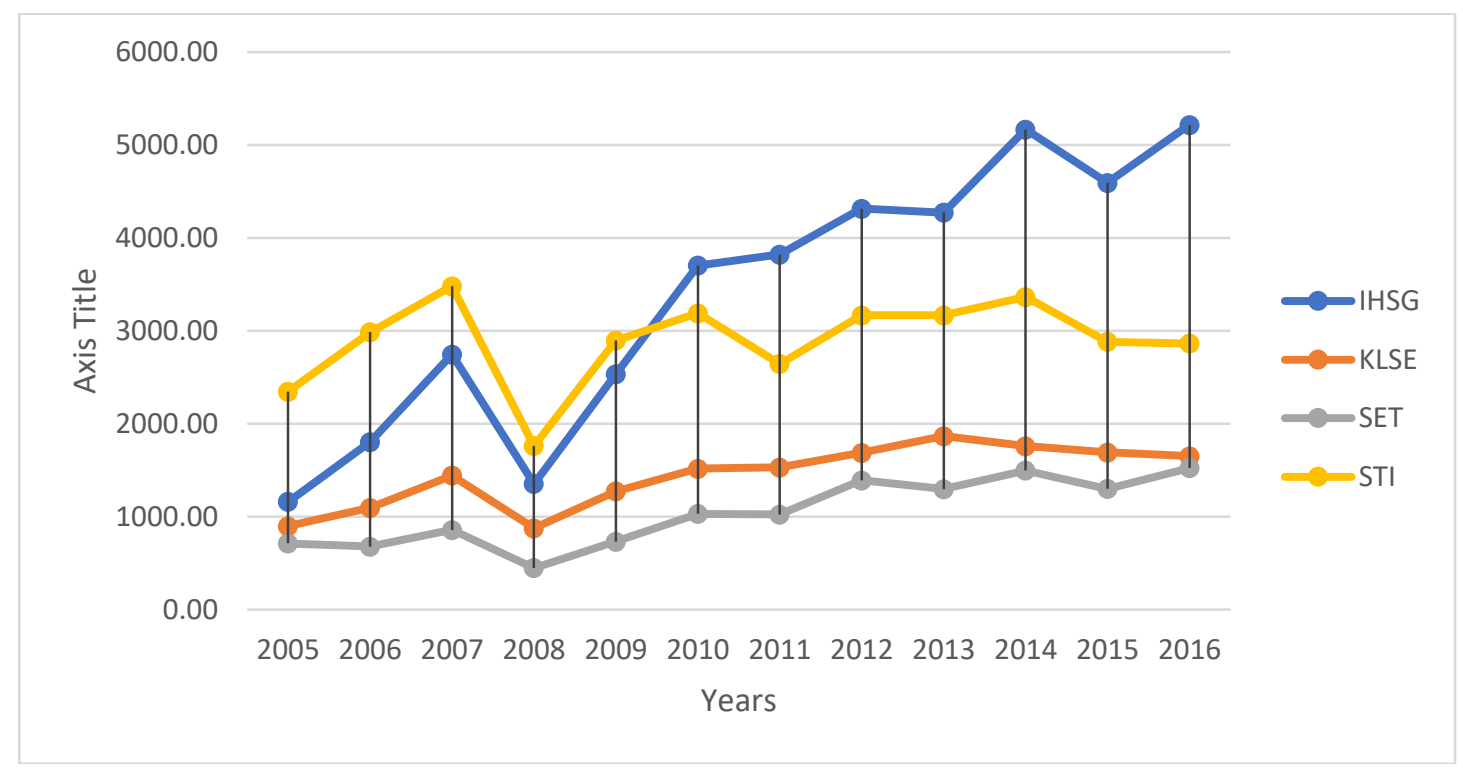

Figure 1

The Movement of Stock Price Index ASEAN Regional

The movement of stock prices regional ASEAN countries cannot be separated from the blow of the financial crisis in the United States and it is interesting to watch, whether the stock movement in the ASEAN region also affects the Jakarta Composite Index in Indonesia. Figure 1.1 shows that the overall movement of stocks ASEAN countries has a tendency to show a positive trend from 2005 to 2015, although at the start of 2007 it has decreased. Moreover, the lowest point occurred in 2008 that caused the global financial crisis triggered by the crisis financial initially in the United States alone. This figure correspond to the research conducted by Madjid and Kasim (2009), that the tests conducted by the US financial crisis in $\mathbf{2 0 0 7}$ have an impact on the performance of the stock market. The result show that the performance of the stock market on average loses its strength each day in comparison with the period before the crisis. Lin (2012) also found that there is a relationship (comovement) between stock prices and exchange rate during the period of crisis. 
INTERNATIONAL JOURNAL OF ACADEMIC RESEARCH IN BUSINESS AND SOCIAL SCIENCES

Vol. 8, No. 12, Dec, 2018, E-ISSN: 2222-6990 @ 2018 HRMARS

\section{Literature Review}

Kontonikas et al (2013), discovered that there is an increase in stock returns during the crisis, when interest rate drop, but the shift in influence occurs when a crisis where the stock does not respond positively to a rate cut in times of crisis, this indicates the inability of monetary policy in maintaining the share price and economic stability. Based on research conducted by Immanuel and Satria (2014), it was found that macroeconomic variables (inflation, exchange rate and interest rate of Indonesian Central Bank) and Index of regional stocks ASEAN significantly influence over both the short and long term, but in the partial test, short-term inflation and interest rate of Indonesian Central Bank has no significant effect on the IHSG, while the exchange rate in the long term and short term significantly impact on IHSG. For ASEAN regional stocks, STI in the long term and short term has no significant effect on the IHSG, while the KLSE (Kuala Lumpur Stock Exchange), SET and PSE (Philippine Stock exchnage) in the long term and short term significantly affect IHSG.

Manurung et al (2014) analyze the effect of the macro variables and several stock indices abroad against IHSG by using VECM (Vector Error Correction) model, found that in the long run all of the variables have a long-term relationship, besides the movement of stock indices abroad in the form Dow Jones, Han Sheng and Nikkei significantly affect IHSG fluctuation. Additionally, Kowanda et al (2014) by using a model of Ordinary Least Square found that variable DJIA (Dow Jones) and STI (Street Times Index) positive and significantly impact on Stock Price Index (CSPI).

Mollick and Assefa, (2013) using GARCH analyze the effect of 2008 global financial crisis on the economy of the United States. The results show that the global crisis in 2008 led to the condition of the US economy under pressure as inflation, oil prices, the weakening exchange rate of USD against the Euro, including the price of leading shares. The same study conducted by Velinov and Chen (2015), by using the model SVAR (Structural Vector Autoregressive) analyzing the impact of the global financial crisis on the stock which discover that global financial crisis also had an impact on the BRIC countries (Brazil, Russia, India and China), consequently the US financial stress in the long run lead to the return of stocks and bonds in these countries far away from the path that it should have been, and give a significantly negative impact.

Another study conducted by Ruiz (2015) using the model SVAR (Structural Vector Autoregressive), explain that shocks of monetary policy conducted by the ECB (European Central Bank) in the form of nominal interest rates have a major impact on stock returns in Spain in the long term. On contrary, Belke and Beckman (2015), by using VAR, concluded that monetary policy issued by the Central Bank is not effective enough to affect the increasing in stock price. Whereas, Zare and Azali (2015) using Asymmetrically Cointegration Method found that in the long term there is a relationship between monetary policy, in this case the policy in raising and lowering interest rates, and stock prices.

Meanwhile, Jin and An (2016) investigated the influence of the global financial crisis on stock prices by using Volatility Impulse Response Function (VIRF), during the crisis period from 2007 to 2009, there is a significant effect of the market in the United States to the stock markets in countries BRICS (Brazil, 
Russia, India, China and South Africa), although the extent of the market reaction to the different markets of other countries. In addition the level of integration of the US stock market and the BRICS cause side effects that might impact more heavily on the volatility of the stock today compared to the era of crisis. The other studies were also conducted by Lu and Sun (2016) examining the relationship between stock prices between BRICS countries with stock prices in the United States during the financial crisis by using the model of VAR and VECM, they found that there were significant effects between the exchange rate and stock returns in short-term. Besides the US stock shocks also significantly affect stock markets in Brazil, China and South Africa.

Reboredo et al (2016) investigates the relationship between stock prices and exchange rates, and the result confirms a positive relationship between exchange rates and stock prices in economy of the developing countries. Meanwhile Ferrer et al, (2016) using the method of wavelet coherence conclude that there is a long-term relationship between interest rates and stock, while others show a weak relationship, the relationship is strengthened significantly after the global financial crisis in the United States.

According to Huang et al (2016) exchange rates and interest rates negatively affect stock prices in the United States. Mensi et al (2016) using VAR Forecasting also find that there is a strong long-term relationship between stock prices in the United States and the stock price in the country of the BRICS (Brazil, Russia, India, China and South Africa), these results are similar to the results of research performed by Velinov and Chen (2015). Yarovaya and Lau (2016) conduct a study to analyze the relationship between UK stock market (UK) with the stock market in the BRICS countries (Brazil, Russia, India, China and South Africa) and MIST (Mexico, Indonesia South Korea and Turkey). The results proved that by using test cointegration the stock market in the BRICS countries and MIST is integrated in the long term.

\section{Data and Methodology}

This study use monthly data from June 2005 to December 2016 of four variables such as Indonesia Composite Index (IHSG), exchange rate, interest rate (BIRATE) and Kuala Lumpur Stock Exchange (KLSE) obtained from Central Bank of Indonesia, Bloomberg and yahoo finances.

The model used in the study is Vector Autoregressive (VAR). Vector Error Correction Model (VECM) is a model of analysis that can be used to determine the short-term behavior of a variable to the longterm ue to a permanent shock (Kostov and Lingard in ajija, 2011). In additions VECM models can also be used to find solutions to the problem of variable time series which is not stationary or spurious correlations in econometric analysis (Ajija: 2011). Analysis of long-term use Vector Error Correction Model (VECM), while the short-term analysis (dynamic) use Vector Autoregressive (VAR). Model VAR / VECM with $n$ endogenous variables is shown by the following equation (Widarjono, 2007):

$$
\begin{array}{lr}
\Delta \text { Yt } & =\beta_{0}+\beta 1 X 1_{t-1}+\beta 2 \Delta X 2_{t-1}+\ldots \ldots \ldots+\beta n X n t-p+\varepsilon 1 t \\
\text { IHSGt } & =\beta_{0}+\beta \text { ERR }_{t-1}+\beta 2 \text { BIRATE }_{t-1}+\beta \text { IHSG }_{t-1}+\beta 4 \text { KLSE }_{t-1}+\varepsilon t \\
\text { ER }_{t}=\beta_{0}+\beta_{1} \text { ER }_{t-1}+\beta_{2} \text { BIRATE }_{t-1}+\beta_{3} \text { IHSG }_{t-1}+\beta_{4} \Delta \text { LKLSE }_{t-1}+\varepsilon t
\end{array}
$$


INTERNATIONAL JOURNAL OF ACADEMIC RESEARCH IN BUSINESS AND SOCIAL SCIENCES

Vol. 8, No. 12, Dec, 2018, E-ISSN: 2222-6990 @ 2018 HRMARS

BIRATE $_{t}=\beta_{0}+\beta_{1}$ ER $_{\mathrm{t}-1}+\beta_{2}$ BIRATE $_{\mathrm{t}-1}+\beta_{3}$ IHSG $_{\mathrm{t}-1}+\beta_{4}$ LLKLE $_{\mathrm{t}-1} 1+\varepsilon \mathrm{t}$

KLSE $_{\mathrm{t}} \quad=\beta_{0}+\beta_{1} \mathrm{ER}_{\mathrm{t}-1}+\beta_{2}$ BIRATE $_{\mathrm{t}-1}+\beta_{3}$ IHSG $_{\mathrm{t}-1}+\beta_{4}$ KLSE $_{\mathrm{t}-1} 1+\varepsilon \mathrm{t}$

Where IHSG represent Jakarta Composite Index, $\beta 0$ represent the constant, ER represent exchanger rate, KLSE represent Kuala Lumpur Stock Exchange and $\varepsilon$ is the error term. After that, the model Johansen co-integration test, impulse response function and variance decomposition have been tested to examine the short run and long run relationship between these variables.

Result and Empirical Analysis

Unit Root Test

Table 4.1

Unit Root Testing Using Philips-Perron Approach

\begin{tabular}{lcccc}
\hline \multirow{2}{*}{ Variable } & \multicolumn{2}{c}{ Level } & \multicolumn{2}{c}{ First Difference } \\
\cline { 2 - 5 } & PP & $\begin{array}{c}\text { Test Critical } \\
\text { Value (10\%) }\end{array}$ & PP & $\begin{array}{c}\text { Test Critical } \\
\text { Value (10\%) }\end{array}$ \\
\hline IHSG & -1.745428 & -3.176618 & -5.082607 & -3.177579 \\
Kurs & -2.032859 & -3.176618 & -5.560550 & -3.177579 \\
BIRATE & -2.905840 & -3.176618 & -3.491198 & -3.177579 \\
KLSE & -1.646375 & -3.176618 & -5.824602 & -3.177579 \\
\hline
\end{tabular}

Source: Test roots units, processed using Eviews 7 (2016)

Table 4.1 displays that all variables are not stationary at level. it can be seen that each variable IHSG, kurs (exchange rate), BIRATE and KLSE is smaller than the critical value at the current level $\mathrm{H}_{0}$, which means the variables are not stationary at level.

Therefore, as the variables are not stationary at level, then all of variables in the study are transformed to first difference. From the test results at first difference, all of variables are stationary, as it is demonstrated in the first difference PP analysis that all variables are greater than the critical value, so that data can be used in this study and as a result, one of the conditions for using the model of Vector Error Correction Model VECM) has been met which is data is stationary at first difference level

\section{Lag Length Criteria}

After that, lag length tested is need to be done in this research. The length of this lag will be used in the cointegration test, causality test and Vector Autoregressive (VAR) estimation model to see which lag is most suitable for the model. The result can be seen from how much a star $\left({ }^{*}\right)$ on each criterion, the numbers lag at the most widely asterisk $\left({ }^{*}\right)$ indicates the lag that is most suitable for this study. 
INTERNATIONAL JOURNAL OF ACADEMIC RESEARCH IN BUSINESS AND SOCIAL SCIENCES Vol. 8, No. 12, Dec, 2018, E-ISSN: 2222-6990 C 2018 HRMARS

Table 4.2

Lag Length Criteria Testing

\begin{tabular}{ccccccl}
\hline \hline Lag & LogL & LR & FPE & AIC & SC & HQ \\
\hline \hline 0 & -3092.629 & NA & $2.61 \mathrm{e}+16$ & 49.15284 & 49.24288 & 49.18942 \\
1 & -2316.580 & 1490.507 & $1.51 \mathrm{e}+11$ & 37.08857 & $37.53878^{*}$ & $37.27148^{*}$ \\
2 & -2296.215 & 37.82155 & $1.41 \mathrm{e}+11^{*}$ & $37.01928^{*}$ & 37.82965 & 37.34851 \\
3 & -2287.292 & 16.00444 & $1.58 \mathrm{e}+11$ & 37.13162 & 38.30215 & 37.60717 \\
4 & -2274.228 & 22.60289 & $1.66 \mathrm{e}+11$ & 37.17822 & 38.70891 & 37.80009 \\
5 & -2265.865 & 13.93867 & $1.88 \mathrm{e}+11$ & 37.29944 & 39.19029 & 38.06763 \\
6 & -2250.167 & 25.16666 & $1.91 \mathrm{e}+11$ & 37.30423 & 39.55525 & 38.21875 \\
7 & -2231.300 & $29.04831^{*}$ & $1.84 \mathrm{e}+11$ & 37.25873 & 39.86991 & 38.31957 \\
8 & -2217.337 & 20.61179 & $1.94 \mathrm{e}+11$ & 37.29107 & 40.26241 & 38.49823 \\
\hline \hline
\end{tabular}

* indicates lag order selected by the criterion

LR: sequential modified LR test statistic (each test at $5 \%$ level)

FPE: Final prediction error

AIC: Akaike information criterion

SC: Schwarz information criterion

HQ: Hannan-Quinn information criterion

\section{Source : Result of research (2016)}

Based on the above test results, lag 2 was selected as the optimum lag, therefore lag 2 need to be inserted in all following tests, so that all information can be inserted into the same research model.

\section{Cointegration Test}

In this study, cointegration test used was Johansen Cointegration Test. Cointegration relationship can be seen from the value of Trace Statistic and Statistic Max Eigen compared with the value of critical value in the 1-10 percent level of confidence. From Table 4.3, it can be seen that the Trace Statistic values is smaller than the critical value $(29.23207<47.85613)$, and the value of the MaxEigen is smaller than the value Statistic Critical Value on the level of trust 1-5 percent ( $15.25855<$ 27.58434). It concluded that in the long term Stock Price Index (CSPI), Exchange Rate, BI Rate, and $\mathrm{KLSE}$, does not have a balance relationship in the long term. 
INTERNATIONAL JOURNAL OF ACADEMIC RESEARCH IN BUSINESS AND SOCIAL SCIENCES Vol. 8, No. 12, Dec, 2018, E-ISSN: 2222-6990 C 2018 HRMARS

Table 4.3

Co-integrating Test

Unrestricted Cointegration Rank Test (Trace)

\begin{tabular}{ccccc}
\hline \hline $\begin{array}{c}\text { Hypothesized } \\
\text { No. of CE(s) }\end{array}$ & Eigenvalue & $\begin{array}{c}\text { Trace } \\
\text { Statistic }\end{array}$ & $\begin{array}{c}0.05 \\
\text { Critical Value }\end{array}$ & Prob.** \\
\hline \hline None & 0.109950 & 29.23207 & 47.85613 & 0.7572 \\
At most 1 & 0.062067 & 13.97352 & 29.79707 & 0.8421 \\
At most 2 & 0.041353 & 5.579393 & 15.49471 & 0.7446 \\
At most 3 & 0.000358 & 0.046964 & 3.841466 & 0.8284 \\
\hline \hline
\end{tabular}

Unrestricted Cointegration Rank Test (Maximum Eigenvalue)

\begin{tabular}{ccccc}
\hline \hline $\begin{array}{c}\text { Hypothesized } \\
\text { No. of CE(s) }\end{array}$ & Eigenvalue & $\begin{array}{c}\text { Max-Eigen } \\
\text { Statistic }\end{array}$ & $\begin{array}{c}0.05 \\
\text { Critical Value }\end{array}$ & Prob.** \\
\hline \hline None & 0.109950 & 15.25855 & 27.58434 & 0.7275 \\
At most 1 & 0.062067 & 8.394122 & 21.13162 & 0.8780 \\
At most 2 & 0.041353 & 5.532429 & 14.26460 & 0.6736 \\
At most 3 & 0.000358 & 0.046964 & 3.841466 & 0.8284 \\
\hline \hline
\end{tabular}

Max-eigenvalue test indicates no cointegration at the 0.05 level

$*$ denotes rejection of the hypothesis at the 0.05 level

**MacKinnon-Haug-Michelis (1999) p-values

Because the Johansen co-integration test shows that this model does not have a long term relationship, as a result we can use model VAR in difference.

\section{Impulse Response Function}

The impulse response of IHSG are shown in Figure 2, where it contains the response of IHSG from shock all of variable. Based on the test IRF (Impulse Response Function) in Figure 2a, IHSG's response to the shock of the exchange rate tends to be positive in the second period and continues to increase and tends to be stable for up to a period of 10. This indicates that monetary policy in maintaining the stability of the rupiah against the US dollar in short-term is effective in maintaining the stability of the IHSG.

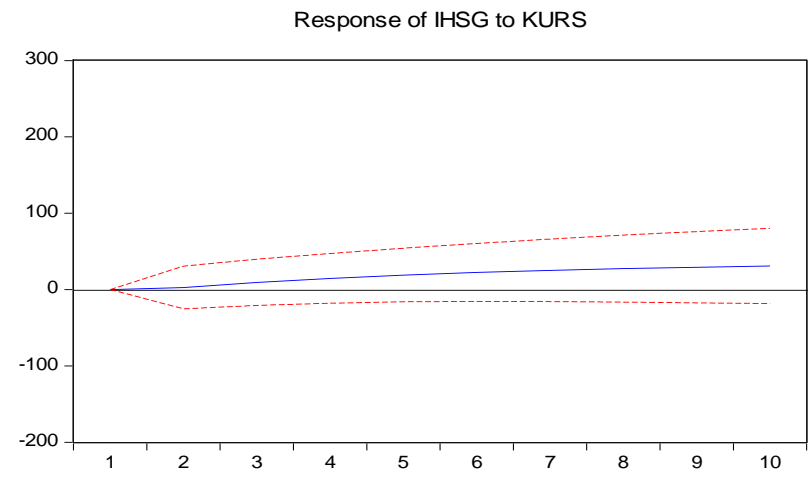


INTERNATIONAL JOURNAL OF ACADEMIC RESEARCH IN BUSINESS AND SOCIAL SCIENCES Vol. 8, No. 12, Dec, 2018, E-ISSN: 2222-6990 @ 2018 HRMARS

Response of IHSG to BIRATE

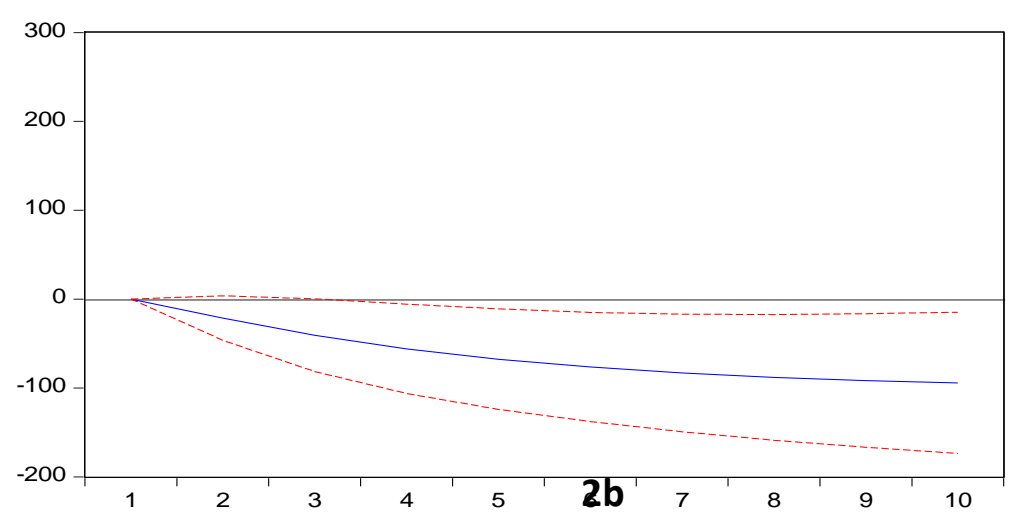

Response of IHSG to KLSE

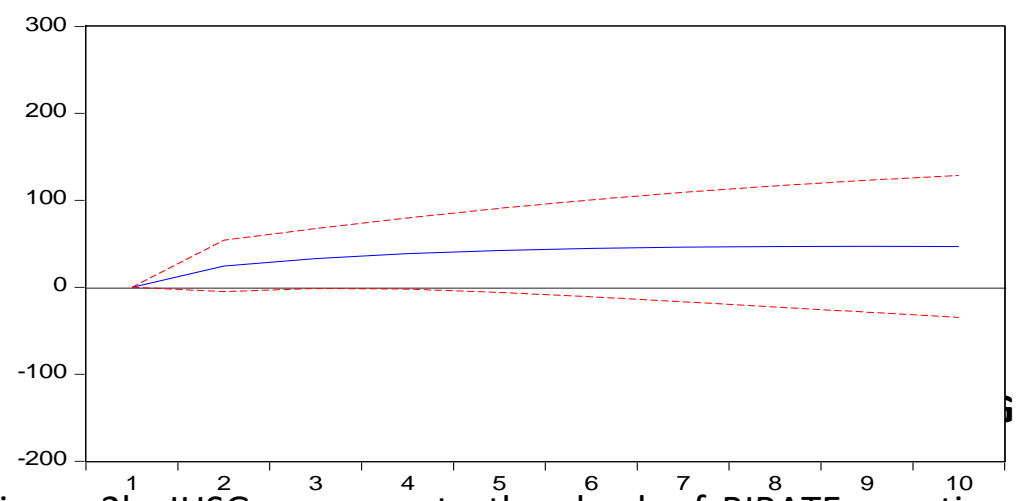

From figure $2 b^{1}$, IHS ${ }^{2}$ response to the shock ${ }^{7}$ of BIRATE ${ }^{4}$ negative and significant from first period to $10^{\text {th }}$ period. It indicates if BIRATE increases then IHSG decreases significantly. On the other hand, IHSG responses to the shock of KLSE is positive, it indicates if KLSE incline, IHSG will incline, which means that KLSE and IHSG has co-movement in short run (figure 2c). 
INTERNATIONAL JOURNAL OF ACADEMIC RESEARCH IN BUSINESS AND SOCIAL SCIENCES Vol. 8, No. 12, Dec, 2018, E-ISSN: 2222-6990 @ 2018 HRMARS

\section{Variance Decomposition}

Table 4.4

Variance Decomposition

\begin{tabular}{|c|c|c|c|c|c|}
\hline \multicolumn{6}{|c|}{ Variance Decomposition of IHSG: } \\
\hline $\begin{array}{l}\text { Perio } \\
\mathrm{d}\end{array}$ & S.E. & IHSG & KURS & BIRATE & KLSE \\
\hline 1 & 164.0047 & 100.0000 & 0.000000 & 0.000000 & 0.000000 \\
\hline 2 & 243.7621 & 98.21305 & 0.010612 & 0.771517 & 1.004816 \\
\hline 3 & 301.5459 & 95.71507 & 0.104186 & 2.327443 & 1.853304 \\
\hline 4 & 347.6490 & 92.76517 & 0.255308 & 4.346552 & 2.632968 \\
\hline 5 & 386.9750 & 89.66672 & 0.444946 & 6.564536 & 3.323798 \\
\hline 6 & 421.8469 & 86.60914 & 0.655276 & 8.811205 & 3.924378 \\
\hline 7 & 453.4968 & 83.70469 & 0.874393 & 10.98515 & 4.435770 \\
\hline 8 & 482.6369 & 81.01007 & 1.094498 & 13.03176 & 4.863680 \\
\hline 9 & 509.7149 & 78.54703 & 1.310821 & 14.92585 & 5.216301 \\
\hline 10 & 535.0341 & 76.31652 & 1.520633 & 16.66002 & 5.502832 \\
\hline
\end{tabular}

Table 4.4 reports the variance decomposition result for the shocks of exchange rate, BIRATE and KLSE. We estimate the percentage of the forecast error in each variable from 1 month to 10 month. Table 4.4 reports how exchange rate shock, BIRATE shock and KLSE shock relate to Jakarta composite index (IHSG). The result show that at 10 month after shocks, the IHSG are explained by BIRATE fluctuation about 16.66 percent, KLSE fluctuation about 5,50 percent and the exchange rate fluctuation only 1,52 percent. It indicates that from all variables, BIRATE has significant influences to IHSG.

\section{Conclusion}

The significant relationship between exchange rate and Kuala Lumpur Stock Exchange (KLSE) can drive Jakarta Composite Index (IHSG) in Indonesia. While, the significant and negatively relationship with BIRATE indicates that monetary policy has been success to reduce Jakarta composite Index (IHSG) in Indonesia. Therefore, this paper explains the monetary policy accomplishment in Indonesia.

\section{References}

Setiawan, A. (2009). "The relationship between the rate of interest of Bank Indonesia Certificates (SBI), Inflation, and Stock Price Index (CSPI)." Journal of Management and Business, Vol. 13, No. 1, Page: 23-33.

Ahmad, W., Sehgal, S., and Bhanumurthy, N.R., (2013). "Eurozone Crisis And Bricks Stock Markets: Contagion Or Market Interdependence?". Economic Model. Page: 209-225.

Ajija, S. R. (2011). Cara Cerdas Menguasai Eviews. Salemba Empat. Jakarta Bank Indonesia. (2008). Statistik Ekonomi Keuangan Indonesia, Jakarta Bhargava, A. (2014). “Firms' Fundamentals, Macroeconomic Variables And Quarterly Stock Prices in the US". Journal of Econometrics. Page : 241-250. 
INTERNATIONAL JOURNAL OF ACADEMIC RESEARCH IN BUSINESS AND SOCIAL SCIENCES Vol. 8, No. 12, Dec, 2018, E-ISSN: 2222-6990 @ 2018 HRMARS

Bianconi, M., Yoshino, J., A., Sousa, M., O., M.,D. (2013). “BRIC and the U.S. Financial Crisis : An Empirical Investigation of Stock and Bond Markets". Emerging Market Review. Page :

76-109.

Boediono. (2011). Ekonomi Moneter. BPFE. Yogyakarta.

Burzala, M., M. (2016). “Contagion Effects In Selected European Capital Markets During The Financial Crisis Of 2007-2009". Research in International Business and Finance. Page :

1-16.

Chen, M.,M., Chen, P.F., dan Lee, C. (2014). "Frontier Stock Market Integration And The Global Financial Crisis". North American Journal of Economics and Finance. Page : 84-103.

Dao, M. Q. (2017). Determinants of the global financial crisis recovery: An emperical assessment. Journal of Economic Studies, 44(1), 36-46; http://dx.doi.org/10.1108/JES-09-20150160.

Dimic, N., Kiviaho, J., Piljak, V., dan Aijo, J. (2016). “Impact of Financial Market Uncertainty And Macroeconomic Factors On Stock-Bond Correlation In Emerging Markets". Research in International Business and Finance. Page : 41-51.

Divianto. (2013). “Analisis Pengaruh Tingkat Inflasi, Tingkat Suku Bunga SBI, Dan Nilai Kurs Dollar AS USD Terhadap Indeks Harga Saham Gabungan IHSG Di Bursa Efek Indonesia”. Jurnal Ekonomi dan Informasi Akuntansi. Vol.2, No.3. Page : 165-197.

Fîrţescu, B. (2012). Causes and Effects of Crises on Financial System Stability in Emerging Countries. Procedia Economics and Finance, 3, $489-495$.

Grout, P. A., Dan Zalewska, A. (2015). "Stock Market Risk In The Financial Crisis". International Review of Financial Analysis.

Gudjarati, D. N. (2010). Dasar - dasar Ekonometrika, Edisi Kelima. Salemba Empat. Jakarta Horta, P., Lagoa, S., dan Martin, L. (2014). "The Impact Of The 2008 And 2010 Financial Crises On The Hurst Exponents Of International Stock Markets: Implications For Efficiency And Contagion". International Review of Financial Analysis. Page : 140-153.

Huang, W., Mollick, A.V., Nguyen, K. H. (2016). "U.S. Stock Markets and The Role of Real Interest Rates". The Quarterly Review of Economics and Finance. Page: 231-242.

Husnan, S. (2000). Dasar-dasar Teori Portofolio dan Analisis Sekuritas di Pasar Modal. UPP AMP

YKPN : Yogyakarta

IMF. (2012). The Effects of Global Financial Shocks on Output in Latin America. Washington DC: IMF; https://www.imf.org/external/pubs/ft/reo/2012/whd/eng/pdf/wreo013013b.pdf.

Informasi Indeks Harga Saham Kuala Lumpur Composite Index. Diakses dari http://www.bloomberg.com/quote/FBMKLCl:IND.

Informasi Indeks Harga Saham Gabungan Indonesia. Diakses dari

http://finance. yahoo.com/q/hp?s=\%5EJKSE\&a $=05 \& b=30 \& c=2005 \& d=11 \& e=31 \& f$

$=2015 \& g=m$.

Informasi Indeks Harga Saham Gabungan Malaysia. Diakses dari

http://finance. yahoo.com/q/hp?s=\%5EKLSE\&a=05\&b=30\&c=2005\&d=11\&e=3\&f=2015

$\& g=m$. 
INTERNATIONAL JOURNAL OF ACADEMIC RESEARCH IN BUSINESS AND SOCIAL SCIENCES Vol. 8, No. 12, Dec, 2018, E-ISSN: 2222-6990 @ 2018 HRMARS

Informasi Indeks Harga Saham Gabungan Singapura. Diakses dari http://finance.yahoo.com/q/hp?s=\%5ESTI\&a=05\&b=30\&c=2005\&d=11\&e=31\&f=2015 $\& g=m$.

Infomasi Nilai Tukar Rupiah. Diakses dari http://www.bi.go.id/id/moneter/informasi kurs/transaksibi/Default.aspx.

Information Interest Rates Bank of Indonesia. Retrieved from http://www.bi.go.id/id/moneter/birate/data/Default.aspx. Information Stock Price Index of Thailand. Retrieved from http://www.set.or.th/en/market/market_statistics.html. Huang. W. Mollick.A.V, dan Nguyen.K.H. 2016. "U.S. Stock Markets And The Role Of Real Interest Rates". The Quarterly Review of Economics and Finance. Page : 231-242. Jin, Xiaoye dan An. Ximeng. 2016. "Global Financial Crisis And Emerging Stock Market Contagion: A Volatility Impulse Response Function Approach". Research in International Business and Finance. Page : 179-195.

Lindström, M., \& Giordano, G. N. (2016). The 2008 financial crisis: Changes in social capital and its association with psychological wellbeing in the United Kingdom: A panel study. Social Science \& Medicine, 153, 71-80.

Litsios, I. (2013). "Exchane Rate Determinantion and Equity Prices : Evidence From The UK". The Journal of Economic Asymmetries. Page : 115-128.

Luchtenberg, K. F., dan Vu, Q. V, (2015)." The 2008 Financial Crisis: Stock Market Contagion And Its Determinants". Research in International Business and Finance . Page : 178-203.

Mahmud, S. (2004). Teori Moneter dan Ekonomi Indonesia. Badan Penerbit Universitas Syiah Kuala. Banda Aceh.

Majid, M. A., dan Kassim, S. H. (2009). "Impact of The 2007 US Financial Crisis On Emerging Equity Markets". International of Emerging Markets. Vol.4 No. 4 : 341-357

Mankiw, N. G. (2003) Teori Makroekonomi, Edisi Kelima, Terjemahan, Jakarta : Erlangga. Manurung, Mandala dan Pratama Rahardja. 2008. Teori Ekonomi Makro. Lembaga Penerbit Fakultas Ekonomi Universitas Indonesia, Jakarta.

Mustafa, N. N., Samsudin, S., Shahadan, F., \& Yi, A. K. (2015). Flight-to-Quality between Stock and Bond Markets: Pre and Post Global Financial Crisis. Procedia Economics and Finance, 31, $846-855$.

Neaime, S. (2012). "The Global Financial Crisis, Financial Linkages And Correlations In Returns And Volatilities In Emerging MENA Stock Markets". Emerging Market Review. Page 268-

282.

Roboredo, J., C., Castro, M., A., R., dan Ugolini, Andrea. 2016. “Downside And Upside Risk Spillovers Between Exchange Rates And Stock Prices". Journal of Banking and Finance. Page :

76-96.

Samarakoon, L., P. 2102. "Stock Market Interdependence, Contagion, and the U.S. Financial crisis: The Case Of Emerging And Frontier Markets". Inernational Financial Markets, Inst. and Money. Page : 724-742.

Samuelson, P. A., dan Nordhaus, W. D. (2001). Makro-Ekonomi, Edisi Keempatbelas. Jakarta : Erlangga 
INTERNATIONAL JOURNAL OF ACADEMIC RESEARCH IN BUSINESS AND SOCIAL SCIENCES Vol. 8, No. 12, Dec, 2018, E-ISSN: 2222-6990 @ 2018 HRMARS

Shen, P. L., Li, W., Wang, X. T., dan Su, C. W. (2015). “Contagion Effect Of The European Financial Crisis On China's Stock Markets: Interdependence And Pure Contagion". Economic Modelling. Page : 193-199. 